\title{
Learning Innovations in the Implementation of Social Distancing Policies in the Covid-19 Pandemic: University Students' Perception
}

\author{
Candra Wijaya ${ }^{1}$, Ilwan Mardani 2, Muhammad Nasir 3, Ishak 4, Ahmad Yani 5 \\ DOI: $10.35445 /$ alishlah.v13i3.771
}

Article Info

Key words:

Learnina Innovation;

Education policu;

Student Perception;

Social Distancing

Kata kunci:

Inovasi Pembelajaran;

Kebijakan Pendidikan;

Persepsi Mahasiswa;

Social Distancing

\begin{abstract}
This paper aims to analyze student perceptions of social distancing in education in the Covid-19 pandemic in the context of educational innovation. The focus of the discussion in this study is how students perceive social distancing in education in the Covid-19 pandemic and the learning patterns applied during the COVID-19 pandemic at the university in Labuhanbatu Utara. This research uses a qualitative approach with a case study method. The data collection techniques are structured interviews with informants (students and lecturers), observation and document study. Furthermore, the data were analyzed using data reduction techniques, descriptive data presentation and concluding. The results of this study indicate that students' perceptions of social distancing in education are a temporary policy issued by the government to anticipate the spread of the Covid19 virus. On this basis, educational institutions (especially universities) apply online learning using the WhatsApp Group (WAG) application, and Zoom Meeting. The main purpose of using online media is as an alternative for learning, assignment and assessment of lectures during the Covid-19 pandemic.
\end{abstract}

\begin{abstract}
Abstrak
Tulisan ini bertujuan menganalisa persepsi mahasiswa tentang social distancing pada pendidikan di masa pandemi covid-19 dalam konteks inovasi pembelajaran. Fokus pembahasan dalam penelitian ini yaitu bagaimana persepsi mahasiswa tentang social distancing pada pendidikan di masa pandemi covid-19 dan pola pembelajaran yang diterapkan selama pandemi covid-19 di salah satu perguruan tinggi Labuhanbatu Utara. Penelitian ini menggunakan pendekatan kualitatif dengan metode studi kasus. Adapun teknik pengumpulan data yaitu wawancara terstruktur dengan informan (mahasiswa dan dosen), observasi dan studi dokumen. Selanjutnya, data dianalisa dengan menggunakan teknik reduksi data, penyajian data secara deskriptif dan penarikan simpulan. Hasil penelitian ini menunjukkan bahwa persepsi mahasiswa tentang social distancing pada pendidikan merupakan kebijakan sementara yang dikeluarkan pemerintah untuk mengantisipasi penyebaran virus Covid-19. Atas dasar ini, lembaga pendidikan (khususnya perguruan tinggi) memberlakukan pembelajaran secara daring (online) menggunakan aplikasi WhatsApp Group (WAG), dan Zoom
\end{abstract}

\footnotetext{
${ }^{1}$ Un iv ersitas Islam Negeri Sumatera Utara, Medan, In donesia Em ail: candrawijaya@uinsu.ac.id

2 Un iv ersitas Islam Negeri Sumatera Utara, Medan, In donesia Em a il: ilwanaceh@gmail.com

3 Un iv ersitas Islam Negeri Sumatera Utara, Medan, Indonesia Em ail: yanura12@gmail.com

4 Un iv ersitas Islam Negeri Sumatera Utara, Medan, Indonesia Em a il: ishakis5555@gmail.com

5 Un iv ersitas Islam Negeri Sumatera Utara, Medan, Indonesia

Em ail: ahmadyanifhy0105@gmail.com
} 
Meeting. Tujuan utama penggunaan media online tersebut yaitu sebagai alternatif dan inovasi pembelajaran, meliputi; penugasan dan penilaian perkuliahan semasa pandemi Covid-19.

\section{INTRODUCTION}

Education is one of the important sectors in life that ensures the sustainability and resilience of each generation (Crul, 2020). Determination of the status of the Covid-19 pandemic (Rohmadani, 2020; Indrawati, 2020) and social distancing policies (Herdiana, 2020), has become a new dimension in the world of education with limited access to face-to-face meetings (Syarifudin, 2020; Pramana, 2020). Limited access to face face in learning process during this pandemic, has an impact on the implementation of the education process, including higher education levels (Indrayana \& Sadikin, 2020:46-55; Sadikin \& Hamidah, 2020: 214-224).

Higher education as an educational institution that prepares prospective undergraduates and superior human resources (HR) in Indonesia has felt the impact of limited face-to-face access during the Covid-19 pandemic (Wijoyo \& Indrawan, 2020; Anhusadar, 2020). Among the problems and impacts caused by learning in the Covid-19 pandemic, namely some students are reluctant to study online (Argaheni, 2020; Indrawati, 2020), the emergence of student distrust about Covid-19 due to confusing information on social media (Latip, 2020; Permatasari, et.al., 2020; Nabila, et.al., 2021), even students are limited to "diving" and community service (Maulah, et.al., 2020).

The various problems above began to be addressed by education providers by presenting a solution-based online learning system for students. For example, the university Labuhanbatu Utara is one of the higher education institutions in the North Sumatra Province. The foundation and high school leaders agreed that learning was carried out in a balanced way between online learning rather than offline. This is a form of obedience by education providers to government policies.

Responding to the policy (agreement) of the foundation and the leadership of the university, caused various perceptions among students. This is in line with the statement from a student of in the university who admitted that this is a temporary policy, so it does not become a principal problem in the learning process, assignment to assessment. Likewise, students also admit that there are weaknesses and strengths in the online learning process.

In connection with relevant research related to student perceptions about online learning and social distancing policies. Indeed, it is easy to find through web searches on Google Scholar, DOAJ, and sign online, as well as other websites. This is based on the number of previous researchers who have discussed similar themes. Among them, namely the research of Pradana, et.al., (2020), which examines social distancing policies from the aspect of influence on vulnerable groups in Indonesia. This study concludes that social distancing has a significant impact on vulnerable groups (pregnant women, children and the elderly), so seriousness and cooperation from every sector of society are needed in its implementation.

Furthermore, there is research by Kresna \& Ahyar (2020) which examines the aspect of its influence on public health. This study found that social distancing policies have a positive impact on public safety and health, but also hurt the economy and social interaction of the community. In line with this research, Engkus, et.al., (2020) informed that the social distancing policy has been very good, but the form of easing entry for foreigners for tourist purposes is a blunder and a serious matter that has an impact on the safety of the Indonesian people, and if it has an impact The increase in the death rate is certainly serious for the community's economy.

Another study was also presented by Syarifudin (2020), who informed that the establishment of social distancing policies necessitated online learning as the only alternative to improve the quality of education in Indonesia during the Covid-19 pandemic. Furthermore, other relevant research is the study conducted by Pratama \& Hidayat (2020) on the understanding and behaviour of the community regarding social distancing. The study concluded that most of the 
public was aware of the existence of a social distancing policy even though the contents of the policy were not analyzed. Because, only a few of the people understand the purpose of the policy as an effort and strategy to prevent the spread of the Covid-19 virus.

Referring to the literature review above, it is known that there is an "empty space" in the analysis of social distancing, namely from the aspect of student perceptions and learning innovation studies. Thus, further and in-depth studies are needed on this matter, which is summarized in the research. Through this research, it is hoped that students will be more objective in looking at the "direction" or orientation of social distancing policies and their solutions to higher education in Indonesia. Furthermore, students can develop their creativity and innovation as agents of change in society.

\section{METHODS}

The approach used in this research is qualitative with the case study method. This is based on a "genre" approach and theme that is suitable for research that aims to explore contemporary things (Yin, 2009: 25). The focus of the discussion in this study is how students perceive social distancing in education in the Covid-19 era and the learning patterns applied during the COVID-19 pandemic at STIT Al-Ittihadiyah Labuhanbatu Utara. This research was conducted from January to June 2021.

The following is a schematic of the research methodology in the chart below:
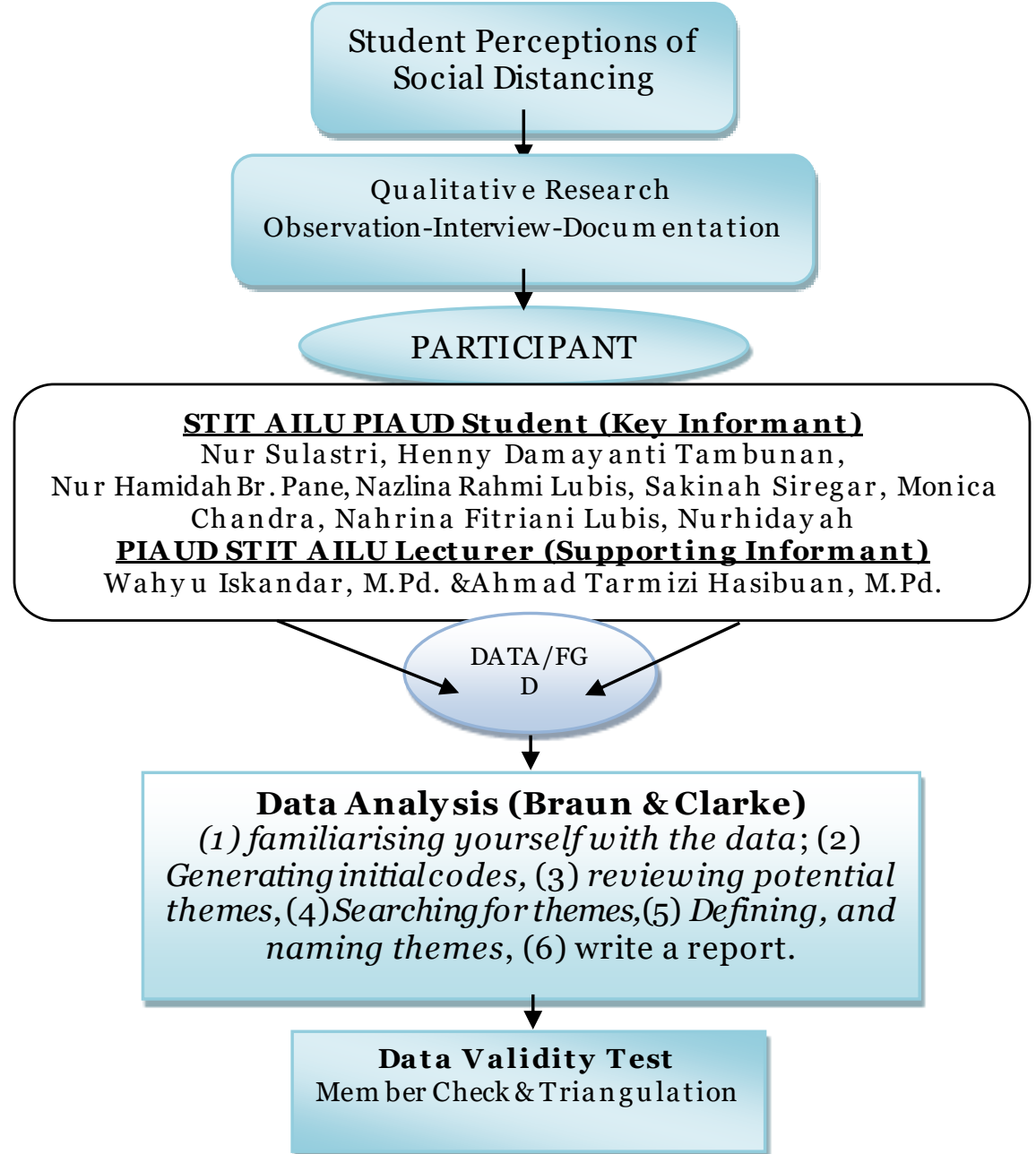

Figure 1. Research Framework Flow.

The participants of this study were 8 (eight) students of PIAUD STIT Al-Ittihadiyah Labuhanbatu Utara, namely, NS, HDT, NHB, NRL, SS, MC, NFL, and NR. There are two supporting informants from the PIAUD lecturers, namely Mr. WI and Mr. ATH Determination of 
participants is done by selecting participants according to the demographics of the study and stating that they are willing to provide the data needed in this study.

Data were collected using individual in-depth interviews. Interviews use telephones to comply with compliance with social distancing. Seidman(2006) informed that telephone interviews can be used to express what participants feel or think about the phenomenon under study. The interview guide was sent via WhatsApp message to participants a week before the interview was conducted. The interview schedule was carried out by agreement between the researcher and the participants (Creswell, 2009; Assingkily, 2021). Interviews were conducted in-depth and recorded with an interview duration of 15-30 minutes per person. Interviews were conducted with openended questions so that participants could use their language to express things that had not been conveyed in the Focus Group Discussion (FGD) (Leavy, 2017: 139). In-depth interviews were conducted by the researchers themselves and assisted by technical personnel to record and make interview transcripts.

The FGD transcripts and in-depth interviews were processed using Braun and Clarke's thematic analysis. Braun \& Clarke (2012) offers 6 (six) steps of thematic analysis. First, familiarize yourself with the data, where the researcher reads the FGD transcripts and interviews over and over again to reveal the richness of information from the data. Second and third Gener ating initial codes, at this stage the researchers coded the data manually to find potential themes. Third, fourth, and fifth reviewing potential themes, Searching for themes, Defining, and naming themes, is done by reviewing potential themes, searching, defining, and naming themes by reading over and over and deciding on the main themes that emerge from the data. Sixth, write a report.

Guarantee of the validity of research data is done by member check and triangulation. Member check is done by allowing the interviewee to comment on the research results in the form of draft articles. Triangulation is done by comparing the results of interviews between one participant and another on the same theme (Creswell, 2009:191).

\section{FINDINGS AND DISCUSSION}

Learning innovation is a necessity during the Covid-19 pandemic situation (Marbun, 2020). This is based on 2 (two) main reasons, namely the community's need for education (Rahmawati \& Putri, 2020) and the sustainability of human life, or in other terms, it is called educational for sustainable development. Online learning as a form of educational technology is part of this innovation or change. However, standardization and special policies related to learning have not been set by the government and also internal institutions (universities) (Rifa'i \& Assingkily, 2021). For example, the latest phenomenon about lecturers "teaching on the road via Zoom meeting" (Mardianto \& Assingkily, 2021) and other examples. Students as agents of change must of course be wise in viewing and analyzing social distancing policies in education in the Covid-19 era.

In response to the description above, the following will further discuss student perceptions of social distancing policies in education in the Covid-19 era as a study of learning innovation.

\section{Student Perceptions of Social Distancing Policy in Education}

Coronavirus disease (Covid-19) has become a threat to human health and has been designated by the World Health Organization (2020) as a global pandemic as of March 11, 2020. In response to this, the government implemented a social distancing policy or social distancing restrictions (Courtemanche, et.al., 2020), to minimize or even avoid the spread of this dangerous virus (Nurhalimah, 2020). Furthermore, Abidah, et.al. (2020:38-49) informed that the social restrictions had an impact on the education sector.

The public's concern about the dangers of the spread of the Covid-19 virus has caused several institutions to "pause" from carrying out learning, some even until now have not car ried out faceto-face learning at all (Tabi'in, 2020; Mushlih, et.al., 2020). In line with this, NS (student of PIAUD STIT Al-Ittihadiyah Labuhanbatu Utara) said: 
"In my opinion, Sir, Social Distancing is a kind of social distancing, Sir, we are asked to keep our distance, wear masks, wash our hands frequently with soap, the term is a health protocol, Sir. Yes... if we look around, it's a good goal, sir, so that we are all safe from this virus whose spread is not visible to the naked eye."

Supporting the interview excerpt above, Siagian (2020) explained that the policy of social distancing or social distancing is a basic reference initiated by the government in protecting the public. Likewise, the limited access of students in studying and playing an extra role (serving) in the community raises new concerns, namely the loss of a generation that is critical of the government and insensitive to society (Crul, 2017). This certainly slows down the nation's achievement in realizing a golden Indonesia in 1 (one) century of independence (Ulum \& Pamungkas, 2020). Furthermore, Rohayani (2020) emphasized that the optimal achievement of a nation is based on superior education and quality (quality) human resources.

In line with the description above, HDT (Student of PIAUD STIT Al-Ittihadiyah Labuhanbatu Utara), said:

"Yes sir, I admit that this social distancing policy is good and maintains health. But, on the other hand, our access as students is limited, sir. If you want to go to campus, it's still under lockdown, if you want to do student activities, it's still forbidden for the campus to carry out activities under the name of the campus when you meet face-to-face with lots of people, because it creates a crowd. So, there are positive and negative sides, sir."

Furthermore, NHB (Student of PIAUD STIT Al-Ittihadiyah Labuhanbatu Utara), said:

"Because of Covid-19, everything is online, sir, for lectures. I'm still in the fourth semester, I feel a little bit like that, sir. You know, sir, you don't feel the campus atmosphere, sir. Everything online. It's going to be easy, sir. So that you can really experience college. But, if it's really against it, face-to-face lectures, it's also wrong, right, sir. So there's a good thing about social distancing, I think, sir."

In line with the above, NRL (Student of PIAUD STIT Al-Ittihadiyah Labuhanbatu Utara), said:

"Regarding social distancing, sir, it seems that students' access to move around campus is very limited, as well as to get involved in the community. Most of the activities during this covid-19 on campus are online, sir, online learning, online lectures, seminars or webinars are also online, paying tuition fees can also be online by transfer. So, everything is online."

Responding to the implementation of the social distancing policy experienced by the students above, it is true that higher education providers implement online learning through online applications (such as WhatsApp Group and Zoom) (Gunawan, et.al., 2020: 61-70). This is considered effective, considering that most Indonesians already have the WhatsApp application and used it in learning before the Covid-19 pandemic (Indaryani \& Suliworo, 2018; Pustikayasa, 2019; Prajana, 2017; Masitoh, et.al., 2018), and Zoom meeting application which was quickly recognized by the Indonesian people after the Covid-19 pandemic was determined (Far-Far, 2021; Vhalery, et.al., 2021).

Likewise, it is recognized that appropriate and measurable standards are needed in the use of online media applications during lectures during the Covid-19 pandemic era (Darwis, et.al., 2020). How come? Lecturers also need to be controlled for the learning process, assignments and assessments (Mardianto \& Assingkily, 2021). If it is necessary to create a special online-based website belonging to the campus (STIT Al-Ittihadiyah Labuhanbatu Utara), to support online learning, the percentage of which is currently 100\%. Even after the Covid-19 pandemic, this kind of website can be used as a form of learning innovation at STIT Al-Ittihadiyah Labuhanbatu Utara. 


\section{Educational Innovations in the Covid-19 Era: Learning, Assignments, and Assessments via Online}

\section{Learning}

Learning is a priority aspect that must continue even in an emergency, including the COVID19 pandemic. This is because learning is the essence of the educational process, which facilitates interaction between students, teachers and learning resources. In the context of higher education levels, Apriani \& Nurhayati (2021) informed that students still need academic studies through lectures (learning processes) to improve higher-order thinking skills. Sumantyo (2020) added this is to maintain the function of students as agents of change in society.

Regarding learning, SS (Student of PIAUD STIT Al-Ittihadiyah Labuhanbatu Utara):

"As agents of change, students still need study space on campus. Because, that is the main capital for students to practice critical thinking skills. Plus indeed by learning and entering the community, Mr. So, be sensitive to the development and condition of society. For this reason, online learning must continue to be carried out as an alternative to lectures during the COVID-19 pandemic."

Supporting the quote above, Akrim, et.al. (2020) explained that the implementation of online learning is an effort to meet the learning needs of students. On this basis, various learning platforms were developed during the Covid-19 pandemic (Gunawan, et.al., 2020: 61-70). The learning platforms in question are WhatsApp Group and Zoom Meeting. As stated by MC (Student of PIAUD ST IT Al-Ittihadiyah Labuhanbatu Utara):

"Yes sir, we usually study using WA for discussion, because the chat messages are like online discussions, sir. Or sometimes we do it by zooming, sir, the term is a virtual face-to-face presentation, sir. However, if such a campus website does not exist, sir. Still using the 2 apps earlier, sir."

Furthermore, NFLsaid:

"If asked which one is more fun, my friends and I would be happier via WA, sir. Because, you don't eat a lot of packets, you can continue to do other activities, and it's not difficult to connect to the network, sir. If the zoom eats a lot of packages, sir, the cellphone heats up quickly, what's more, difficult is the network sometimes sucks, sir."

Observing the two interview quotes above, it is understood that the STIT Al-Ittihadiyah Labuhanbatu Utara campus has not provided online learning facilities owned by the institution, such as campus e-learning or other types, but still uses general social media applications such as WhatsApp and Zoom. Criticizing this, Elyana (2020) explained that educational institutions need to immediately innovate in facilitating student learning with effective management and utilizing the institution's online media. Delima, et.al. (2021) added, this was done so that learning could be coordinated and monitored by the institution regularly.

Thus, it is understood that online learning carried out at STIT Al-Ittihadiyah Labuhanbatu

Utara uses WhatsApp and Zoom applications. Where, the WhatsApp application is used as a vehicle or discussion medium, while Zoom is a medium for group discussion presentations. Likewise, as an innovative effort during the Covid-19 pandemic, the campus leadership or foundation needs to design an online media or e-learning website belonging to the institution, as a student learning facility in the Covid-19 pandemic.

\section{Assignment}

The assignment is an important aspect in training students' sense of responsibility for the material that has been taught (Trinova, 2012). Through assignments, educators also understand the level of ability of students to accept the material that has been taught (Ramli, 2015; Amini, 2015). Moreover, students at the higher education level, of course, have to be extra looking for and 
dig up information, rather than just waiting for information and learning from lecturers (educators) (Izni, 2019).

Regarding the assignment aspect, the PIAUD lecturer at STIT Al-Ittihadiyah Labuhanbatu Utara gave individual and group assignments to students. The individual assignments are in the form of quizzes and scientific articles, while group assignments include mini-research and group discussions. As stated by NH (PIAUD ST IT Al-Ittihadiyah Labuhanbatu Utara Student):

"Even though we study online, sir, we are still given assignments by the lecturers, sometimes there are 1-2 assignments per course, sometimes just a resume. Each one, sir, according to the way the lecturer teaches. There are individual tasks, sir, such as quizzes or being asked to write scientific articles. The most frequent, of course, are your group assignments, sir, we were asked for a mini-research on early childhood and a presentation on your group assignments, sir. That's all sir, all the online lectures and assignments are piled up, sir."

Commenting on the quote above, Taufiq (2018) explains that the new paradigm of higher education institutions in Indonesia must give an impression or meaning to every process that students go through. Not only, making lectures a formality, but must train and prepare students as superior human resources needed by the global community. This is certainly the answer to the old paradigm about the meaning of tasks that are perceived as a burden for students (Rohmawati, 2012; Sit. \& Assingkily, 2020).

Thus, it is understood that the online assignments carried out at STIT Al-Ittihadiyah Labuhanbatu Utara also use online media, including individual assignments and group assignments. The individual tasks are quizzes and scientific articles, while the group assignments include mini-research and presentation of the results of group discussions. Furthermore, the meaning of the task during a pandemic situation is not an effort to burden students, but to train and nurture students to be ready to become superior human resources in the global community.

\section{Assessment}

Assessment is an effort to measure the learning achievement of students (Rahmawati \& Gajewski, 2018; Abdullah, 2015). Through this stage, students personally know their level of competence in a certain period. For this reason, the role of educators is needed in providing motivation and input that must be addressed by students. In this regard, Mr. WI (one of the PIAUD lecturers at STIT Al-Ittihadiyah Labuhanbatu Utara) said:

"This assessment is important, sir, because students can measure their abilities for 1 (one) semester, and lecturers are also able to observe the level of students' ability to accept the material they teach. It's like a kind of academic introspection, sir. Likewise, in this era of the Covid-19 pandemic, it is rather difficult to assess the attitude aspect of Mr. Because, we do not face to face and directly observe the movements of students, even though we can virtually see them on Zoom. But, that's not enough sir. Other assessments, such as skills and cognitive skills, are still quite easy, sir, thanks to the help of this online media."

In line with the interview above, Mr ATH (PIAUD STIT Al-Ittihadiyah North Labuhanbatu lecturer) also said:

"Yes, sir, for the Covid-19 era, it is rather difficult to set an example for students, in contrast to face-to-face lectures. Likewise with them, it is difficult for us to judge whether they are actively participating in college or not because via ZOOM and WA they can do other activities. If we make it firm ourselves, such as zoom, we have to show video, because the network is slow. So it is difficult for us to control student learning behaviour, sir, from the government and internal campuses, there is also no 
special policy for this online tuition standard, sir. If the written assignments and skills are still safe, sir."

Based on the interview excerpt above, it is understood that the assessment aspect is still being carried out at STIT Al-Ittihadiyah Labuhanbatu Utara, even amid the Covid-19 pandemic situation. However, the lecturers also complained about the standard of learning assessment given to students from the aspect of attitude or learning behaviour (affective). For this reason, it is a separate note for higher education providers to make internal and national policies regarding online learning assessment standards.

\section{CONCLUSION}

Based on the results and discussion of the research above, it can be concluded that social distancing in education is perceived by PIAUD STIT Al-Ittihadiyah Labuhanbatu Utara students as a temporary policy (due to an emergency/pandemic) to anticipate the spread of the Covid-19 virus in Indonesia. Alternative lectures, including the learning process, assignments, and assessments at STIT Al-Ittihadiyah Labuhanbatu Utara are carried out online, using the WhatsApp Group and Zoom Meeting applications. lectures. If possible, create an online learning application (e-learning) belonging to the campus as a form of the institution's readiness to innovate.

\section{REFERENCES}

Abdullah, Ramli. (2015). "Urgensi Penilaian Hasil Belajar Berbasis Kelas Mata Pelajaran IPS di Madrasah T sanawiyah" LantanidaJournal, 3(2). http://dx.doi.org/10.22373/lj.v3i2.1657.

Abidah, Azmil, et.al. (2020).“The Impact of Covid-19 to Indonesian Education and Its Relation to the Philosophy of "Merdeka Belajar" SIPOSE: Studies in Philosophy of Science and Education, 1(1):38-49. https://doi.org/10.46627/sipose.v1i1.9.

Akrim, et.al. (2020). "Covid-19 \& Kampus Merdeka di Era New Normal” Kumpulan Buku Dosen. Medan: UMSU Press. https://publication.umsu.ac.id/index.php/bk/article/view/591.

Amini, Mukti. (2015). "Profil Keterlibatan Orang Tua dalam Pendidikan Anak Usia TK" VISI: Jurnal Ilmiah Pendidik dan Tenaga Kependidikan Pendidikan Non Formal, 1o(1). https://doi.org/10.21009/JIV.1001.2.

Anhusadar, Laode. (2020). "Persepsi Mahasiswa PIAUDTerhadap Kuliah Online di Masa Pandemi Covid 19" Kindergarten: Journal of Islamic Early Childhood Education, 3(1). http://ejournal.uin-suska.ac.id/index.php/KINDERGARTEN/article/view/9609.

Apriani, Wiwin \& Nurhayati. (2021). "Hubungan Hasil Belajar Daring dengan Minat dan Motivasi Belajar Mahasiswa di Era Pandemi Covid-19” EduMatSains: Jurnal Pendidikan, Matematika dan Sains, 6(1). http://ejournal.uki.ac.id/index.php/edumatsains/article/view/3001.

Argaheni, Niken Bayu. (2020). "Sistematik Review: Dampak Perkuliahan Daring Saat Pandemi COVID-19 Terhadap Mahasiswa Indonesia" Placentum: Jurnal Ilmiah Kesehatan dan Aplikasinya, 8(2). https://jurnal.uns.ac.id/placentum/article/view/43008.

Asfiati \& Nur Imam Mahdi. (2020). "Merdeka Belajar bagi Anak Berkebutuhan Khusus di SLB Kumala Indah Padangsidimpuan” Kindergarten: Journal of Islamic Early Childhood Education, 3(1). http://dx.doi.org/10.24014/kjiece.v3i1.9620.

Assingkily, Muhammad Shaleh. (2021). Penelitian Tindakan Kelas (Meneliti dan Membenahi Pendidikan dari Kelas). Medan: CV. Pusdikra Mitra Jaya.

Astini, Ni Komang Suni. (2020). “Tantangan dan Peluang Pemanfaatan Teknologi Informasi dalam Pembelajaran Online Masa Covid-19” Cetta: Jurnal Ilmu Pendidikan, 3(2): 241-255. https://doi.org/10.33449/jpmr.v5i2.11410.

Awofala, Adeneye O. A. (2020). "Covid-19 Pandemic in Nigeria and Attitudes Towards Mathematics Homeschooling Among Pre-Tertiary Students" Nigerian Online Journal of Educational Sciences Technology, 1(2). http://jepa.unilag.edu.ng/index.php/nojest/article/view/915.

Braun, V. \& Clarke, V. (2012). Thematic analysis. In H. Cooper, P. M. Camic, D. L. Long, A. T. Panter, D. Rindskopf, \& K. J. Sher (Eds), APA handbook of research methods in psychology, Vol. 2: Research designs: Quantitative, qualitative, neuropsychological, and biological (pp. 57-71). Washington, DC: American Psychological Association. 
Cahyati, Nika \& Rita Kusumah. (2020). "Peran Orang Tua dalam Menerapkan Pembelajaran di Rumah Saat Pandemi Covid 19" Jurnal Golden Age, 4(1). http://www.ejournal.hamzanwadi.ac.id/index.php/iga/article/view/2203.

Courtemanche, Charles, et.al. (2020)."Strong Social Distancing Measures in the United States Reduced the Covid-19 Growth Rate" Health Affairs, 39(7). https://doi.org/10.1377/hlthaff.2020.00608.

Creswell, John W. (2009). Research Design Qualitative, Quantitative, and Mixed Methods Approaches. California: SAGE Publications, Inc.

Crul, Maurice, et.al. (2017)."No Lost Generation? Education for Refugee Children". http://hmm.igeucla.org/wp-content/uploads/2017/o1/Education-for-refugee-children-Crulet-al-DRAFT.pdf.

Darwis, Dedi, et.al. (2020). "Peran Sistem Pembelajaran dalam Jaringan (SPADA) Sebagai Solusi Pembelajaran pada Masa Pandemi Covid-19 di SMK YPI Tanjung Bintang" Prosiding Seminar Nasional Darmajaya, https://jurnal.darmajaya.ac.id/index.php/PSND/article/view/2462.

Delima, Nur, et.al. (2021). "Pembelajaran Fiqih Berbasis E-Learning di Era New Normal di Madrasah Tsanawiyah Darud Da’wah wal Irsyad Benteng Kecamatan Sungai Batang Provinsi Riau" Skripsi. Jambi: UIN Sulthan Thaha Saifuddin Jambi. http://repository.uinjambi.ac.id/8177/.

Dewi, Wahyu Aji Fatma. (2020). "Dampak Covid-19 Terhadap Implementasi Pembelajaran Daring di Sekolah Dasar" Edukatif: Jurnal Ilmu Pendidikan, 2(1): 55-61. https://core.ac.uk/reader/322536540.

Ellanur, Carona. (2017). "Pemanfaatan Aplikasi WhatsApp sebagai Sarana Diskusi antara Pengawas dan Guru Pendidikan Agama Islam” Jurnal As-Salam, 1(2): 1-14. http://www.jurnal-assalam.org/index.php/JAS/article/view/80.

Elyana, Luluk. (2020). "Manajemen Parenting Class Melalui Media E-Learning” Sentra Cendekia, 1(1). http://e-journal.ivet.ac.id/index.php/jsc/article/view/1191.

Engkus, Suparman, et.al. (2020). “Covid-19: Kebijakan Mitigasi Penyebaran dan Dampak Sosial Ekonomi di Indonesia" Artikel KTI LP2M UIN Sunan Gunung Djati Bandung. http://digilib.uinsgd.ac.id/30820/.

Far-Far, Gazali. (2021). "Efektivitas Penggunaan Aplikasi Zoom Meeting dalam Pembelajaran di Masa Pandemi Covid-19" Istoria: Jurnal Pendidikan dan Sejarah, 17(1). https://journal.uny.ac.id/index.php/istoria/article/view/37421.

Gunawan, et.al. (2020)."Variations of Models and Learning Platforms for Prospective Teachers During the Covid-19 Pandemic Period" Indonesian Journal of Teacher Education, 1(2): 6170. https://journal.publication-center.com/index.php/ijte/article/view/95.

Hanoatubun, Silpa. (2020). "Dampak Covid-19 Terhadap Perekonomian Indonesia" EduPsyCouns: Journal of Education, Psychology and Counseling, 2(1): 146-153. https://ummaspul.ejournal.id/Edupsycouns/article/view/423.

Hennick, Monique M. (2014). Focus Group Discussions. NewYork: Oxford University Press.

Herdiana, Dian. (2020). "Social Distancing: Indonesian Policy Response to The Corona Virus Disease 2019 (Covid-19)” Jurmal Ilmu Administrasi, $17(1)$. https://doi.org/10.31113/jia.v17i1.555.

Hewi, La \& Linda Asnawati. (2020). "Strategi Pendidik Anak Usia Dini Era Covid-19 dalam Menumbuhkan Kemampuan Berpikir Logis” Jurnal Obsesi, 5(1). https://doi.org/10.31004/obsesi.v5i1.530.

Ikhsan, et.al. (2020).“Upaya Perlindungan Anak dalam Peradilan Pidana di Era Pemberlakuan 'New Normal' Selama Pandemi Covid-19 di Indonesia" Jurnal Ilmu Hukum, 9(2). http://dx.doi.org/10.30652/jih.vgi2.7933.

Indaryani, Eka \& Dwi Suliworo. (2018). "Dampak Pemanfaatan WhatsApp dalam Meningkatkan Motivasi Belajar Siswa pada Pelajaran Fisika" Quantum: Seminar Nasional Fisika dan Pendidikan Fisika $U A D$ Yogyakarta. http://seminar.uad.ac.id/index.php/quantum/article/view/229.

Indrawati, Budi. (2020). "Tantangan dan Peluang Pendidikan Tinggi dalam Masa dan Pasca Pandemi Covid-19” Jurnal Kajian Ilmiah, 1(1):39-48. https://doi.org/10.37092/ej.v3i1.224. 
Indrayana, Boy \& Ali Sadikin. (2020). "Penerapan E-Learning di Era Revolusi Industri 4.0 untuk Menekan Penyebaran Covid-19" Indonesian Journal of Sport Science and Coaching, 2(1): 4655. https://doi.org/10.22437/bio.v6i2.9759.

Izni, Infazatul. (2019). "Kemampuan Literasi Digital dalam Menilai Berita Hoax di Media Daring Kalangan Mahasiswa Aktivis Universitas Airlangga Surabaya” Skripsi. Surabaya: Universitas Airlangga. http://repository.unair.ac.id/91619/.

Kresna, Arief \& Juni Ahyar. (2020). "Pengaruh Physical Distancing dan Social Distancing Terhadap Kesehatan dalam Pendekatan Linguistik" Jurnal Syntax Transformation, 1(4). http://jurnal.syntaxtransformation.co.id/index.php/jst/article/view/42.

Kurniawan, Yosep. (2020). "Implementasi Merdeka Belajar Berdasarkan Ajaran Tamansiswa dalam Pembelajaran Bahasa Inggris Lembaga Kursus Kelas Anak-anak” Seminar Nasional $\begin{array}{lccc}\text { Pendidikan } & 7 & \text { Maret } & \end{array}$ http://jurnal.ustjogja.ac.id/index.php/semnas2020/article/view/7375.

Latip, Abdul. (2020). "Peran Literasi Teknologi Informasi dan Komunikasi pada Pembelajaran Jarak Jauh di Masa Pandemi Covid-19" EduTeach: Jurnal Edukasi dan Teknologi Pembelajaran, 1(2), 2020.

Leavy, Patricia. (2017). Research Design Quantitative, Qualitative, Mixed Methods, Arts-Based, and Community-Based Participatory Research Approaches. New York:The Guilford Press

Marbun, Purim. (2020). "Desain Pembelajaran Online pada Era dan Pasca Covid-19" Computer Science Research and Its Development Journal, 12(2): 129-142. http://dx.doi.org/10.22303/csrid.12.2.2020.129-142.

Mardianto \& Muhammad Shaleh Assingkily. (2021). "Dosen Ngajar On the Road: Persepsi Mahasiswa tentang Fenomena Pembelajaran Era Covid-19" Jurnal Obsesi: Jurnal Pendidikan Anak Usia Dini, 6(1). https://doi.org/10.31004/obsesi.v6i1.1374.

Masitoh, Sellawati Nurul, et.al. (2018). "Model Pembelajaran Berbasis Blended Learning Melalui Media WhatsApp dalam Menumbuhkan Critical Thinking pada Siswa SD” Prosiding Seminar Nasional Pendidikan Guru Sekolah Dasar, FKIP e-Proceeding. https://jurnal.unej.ac.id/index.php/fkip-epro/article/view/9373.

Maulah, Sidatul, et.al. (2020). "Persepsi Mahasiswa Biologi Terhadap Perkuliahan Daring Sebagai Sarana Pembelajaran Selama Pandemi Covid 19" ALVEOLI: Jurnal Pendidikan Biologi, 1(2). https://alveoli.iain-jember.ac.id/index.php/alv/article/view/6.

Mauly, Yuka Kholyssa. (2020). "Metode Pembelajaran Daring Menggunakan Aplikasi Online pada Masa Pandemi Covid-19 di SMPIT Az-Zahra Sragen Tahun Pembelajaran 2019/2020" Skripsi. Surakarta: Universitas Muhammadiyah Surakarta. http://eprints.ums.ac.id/84044/.

Mushlih, Miftahul, et.al. (2020)."Pendampingan Sekolah Dasar Neger 4 Kupang, Jabon dalam Menghadapi New Normal" Humanism: Jurnal Pengabdian Masyarakat, 1(2). http://dx.doi.org/10.30651/hm.v1i2.5565.

Mustaghfiroh, Siti. (2020). "Konsep 'Merdeka Belajar' Perspektif Aliran Progresivisme John Dewey" Jurnal Studi Guru dan Pembelajaran, 3(1): 141-147. https://doi.org/10.30605/jsgp.3.1.2020.248.

Nabila, Farisa Habibati, et.al. (2021). "Penerapan Gaya Belajar yang Efektif Selama Pandemi Covid-19 Menggunakan Media Online di Universitas Pamulang" Proceeding Secretari Universitas Pamulang, $1(1)$. http://www.openjournal.unpam.ac.id/index.php/PSU/article/view/9708.

Naserly, Mursyid Kasmir. (2020). "Implementasi Zoom, Google Classroom, dan WhatsApp Group dalam Mendukung Pembelajaran Daring (Online) pada Mata Kuliah Bahasa Inggris Lanjut (Studi Kasus pada 2 Kelas Semester 2, Jurusan Administrasi Bisnis, Fakultas Ekonomi dan Bisnis, Universitas Bina Sa)” Aksara Public, 4(2): 155-165. http://aksarapublic.com/index.php/home/article/view/417.

Nurhalimah, Neneng. (2020). "Upaya Bela Negara Melalui Social Distancing dan Lockdown untuk Mengatasi Wabah Covid-19 (Efforts to Defend the Country Through Social Distancing and Lockdown to Overcome the Covid-19 Plague)" SSRN. https://dx.doi.org/10.2139/ssrn.3576405.

Perdana, Novan Satria. (2015). "Faktor-faktor yang Berpengaruh Terhadap Aksesbilitas Memperoleh Pendidikan untuk Anak-anak di Indonesia" Jurnal Pendidikan dan Kebudayaan, 21 (3):279-297. https://core.ac.uk/download/pdf/227142787.pdf. 
Permatasari, Andalusia Neneng, et.al. (2020)."Keintiman Komunikasi Keluarga saat Social Distancing Pandemi Covid-19” JurnalObsesi, 5(1). https://doi.org/10.31004/obsesi.v5i1.577.

Pradana, Anung Ahadi, et.al. (2020). "Pengaruh Kebijakan Social Distancing pada Wabah COVID19 Terhadap Kelompok Rentan di Indonesia" Jurnal Kebijakan Kesehatan Indonesia, 9(2). https://journal.ugm.ac.id/jkki/article/view/55575/o.

Prajana, Andika. (2017). "Pemanfaatan Aplikasi WhatsApp untuk Media Pembelajaran dalam Lingkungan UIN Ar-Raniry Banda Aceh" Cyberspace: Jurnal Pendidikan Teknologi Informasi, 1(2). http://103.107.187.25/index.php/cyberspace/article/view/1980.

Pramana, Cipta. (2020). "Pembelajaran Pendidikan Anak Usia Dini (PAUD) di Masa Pandemi Covid-19" Indonesian Journal of Early Childhood, 2(2). http://dx.doi.org/10.35473/ijec.v2i2.557.

Pratama, Novian Agung \& Dasrun Hidayat. (2020). "Pengetahuan dan Perilaku Masyarakat Memaknai Social Distancing” Journal Digital Media \& Relationship, 2(1). http://ejurnal.ars.ac.id/index.php/idigital/article/view/270.

Purnamasari, Iin. (2017). "Homeschooling dalam Potret Politik Pendidikan: Studi Etnografi pada Pelaku Homeschooling di Yogyakarta" Journal of Nonformal Education, 3(1). https://doi.org/10.15294/jne.v3i1.8844.

Pustikayasa, I Made. (2019). "Grup WhatsApp Sebagai Media Pembelajaran” Widya Genitri: Jurnal Ilmiah Pendidikan, Agama dan Kebudayaan Hindu, 1o(2). http://jurnal.stahds.ac.id/widyagenitri/article/view/281.

Rahmawati, Laili Etika \& Dawid Michal Gajewski. (2018). "Urgensi Penilaian dalam Pembelajaran BIPA” Publikasi Ilmiah. http://hdl.handle.net/11617/9904.

Rahmawati \& Evita Muslima Isnanda Putri. (2020). "Learning From Home dalam Perspektif Persepsi Mahasiswa Era Pandemi Covid-19” Prosiding Seminar Nasional Hardiknas, 1(1). http://proceedings.ideaspublishing.co.id/index.php/hardiknas/article/view/3.

Ramli, M. (2015). "Hakikat Pendidik dan Peserta Didik" Tarbiyah Islamiyah: Jurnal Ilmiah Pendidikan Agama Islam, 5(1). https://dx.doi.org/10.18592/jt\%20ipai.v5i1.1825.

Rifa'i, Muhammad \& Muhammad Shaleh Assingkily. (2021). "Lisik: Lima Pilar Kebijakan Internal Kepala RA Al Hijrah Badrul Ulum dalam Menciptakan Iklim Belajar Kondusif” Jurnal Obsesi: Jurnal Pendidikan Anak Usia Dini, 6(1). https://obsesi.or.id/index.php/obsesi/article/view/1098.

Rohayani, Farida. (2020). "Menjawab Problematika yang Dihadapi Anak Usia Dini di Masa Pandemi Covid-19" Qawwam, 14(1). https://doi.org/10.20414/qawwam.v14i1.2310.

Rohmadani, Adinda Icha. (2020). "Dampak Covid 19 Terhadap Cara Berpikir dalam Pembelajaran Daring: Studi Kasus di Yogyakarta” Edification Journal: Pendidikan Agama Islam, 3(1). https://doi.org/10.37092/ej.v3i1.224.

Rohmawati, Cicik. (2012). "Usaha Guru untuk Mengatasi Kenakalan Anak Kelas V SD Negeri Kliwonan 2 Masaran Sragen Tahun Pelajaran 2011/2012” Skripsi. Surakarta: Universitas Muhammadiyah Surakarta. http://eprints.ums.ac.id/21193/.

Ruhaena, Lisnawati \& Juni Ambarwati. (2015). "Pengembangan Minat dan Kemampuan Literasi Awal Anak Prasekolah di Rumah" Publikasi Ilmiah UMS, The $2^{\text {nd }}$ University Research Colloquium (URECOL) 2015. http://hdl.handle.net/11617/6881.

Sadikin, Ali \& Afreni Hamidah. (2020). "Pembelajaran Daring di Tengah Wabah Covid-19" Biodik: Jurnal Ilmiah Pendidikan Biologi, 6(2): 214-224.https://doi.org/10.22437/bio.v6i2.9759.

Seidman, I. 2006. Interviewing as qualitative research. A guide for researchers in education and the social sciences . New York and London: Teachers College, Columbia University. [Google Scholar]

Siagian, Tiodora Hadumaon. (2020). "Mencari Kelompok Berisiko Tinggi Terinfeksi Virus Corona dengan Discourse Network Analysis" Jurnal Kebijakan Kesehatan Indonesia, 9(2). https://doi.org/10.22146/jkki.55475.

Sit., Masganti \& Muhammad Shaleh Assingkily. (2020). "Persepsi Guru tentang Social Distancing pada Pendidikan AUD Era New Normal" Jurnal Obsesi: Jurnal Pendidikan Anak Usia Dini, 5(2). https://www.obsesi.or.id/index.php/obsesi/article/view/756.

Sumantyo, Franciscus Dwikotjo Sri. (2020). "Pendidikan Tinggi di Masa dan Pasca Covid-19" Jurnal Kajian Ilmiah, 1(1). https://doi.org/10.31599/jki.v1i1.266.

Syarifudin, Albitar Septian. (2020). "Implementasi Pembelajaran Daring untuk Meningkatkan Mutu Pendidikan Sebagai Dampak Diterapkannya Social Distancing” Metalingua: Jurnal 

Pendidikan
Bahasa
dan
Sastra
Indonesia,
$5(1)$

https://doi.org/10.21107/metalingua.v5i1.7072.

Tabi'in, A. (2020). "Problematika Stay at Home pada Anak Usia Dini di Tengah Pandemi Covid 19" Jurnal Golden Age, 4(1). journal.hamzanwadi.ac.id/index.php/iga/article/view/2244.

Tarma \& Uswatun Hasanah. (2017). "Workshop Parental Control Berbasis Android untuk Mencegah Akses Konten Pornografi pada Anak Usia Sekolah Dasar di Desa Cililin Kecamatan Cililin Kabupaten Bandung Barat" Sarwahita: Jurnal Pengabdian kepada Masyarakat,14(2). https://doi.org/10.21009/sarwahita.142.09.

Taufiq, Ahmad. (2018). "Paradigma Baru Pendidikan Tinggi dan Makna Kuliah Bagi Mahasiswa" MADANI: Jurnal Politik dan Sosial Kemasyarakatan, 1O(1). https://doi.org/10.52166/madani.v10i1.938.

Trinova, Zulvia. (2012). "Hakikat Belajar dan Bermain Menyenangkan Bagi Peserta Didik" AlTa'lim Journal, 19(3). https://doi.org/10.15548/it.v19i3.55.

Ulinnuha, Masyari. (2013). "Melindungi Anak dari Konten Negatif Internet: Studi Terhadap $\begin{array}{lllll}\text { Peramban Web Kasus Anak" } & \text { 8(2). }\end{array}$ https://journal.walisongo.ac.id/index.php/sawwa/article/viewFile/661/599

Ulum, Muhammad Syahrul \& Jati Pamungkas. (2020). "Analisis Kritis Penerapan Metode Pembelajaran Berbasis Online di Madrasah Ibtidaiyah Masa Pandemi Covid 19 (Solusi Menyelamatkan Masa Depan Anak-anak Indonesia)" Mubtadi: Jurnal Pendidikan Ibtidaiyah, 2(1). http://dx.doi.org/10.19105/mubtadi.v2i1.3584.

Vhalery, Rendika, et.al. (2021). "Pembelajaran Berbasis Online Zoom pada Kesiapan Belajar Mahasiswa di Masa Pandemi Covid-19" Research and Development Journal of Education, 7(1). https://journal.lppmunindra.ac.id/index.php/RDJE/article/view/9329.

Wekke, Ismail \& Ahmad Saleh. (2020). "Pembelajaran di Masa Pandemi: Tidak Hanya Metode Daring Saja” OSFpreprints. https://doi.org/10.31219/osf.io/njtku.

World Health Organization (WHO). (2020). Pandemic Global Covid-19. https://apps.who.int/iris/bitstream/handle/10665/336034/nCoV-weekly-sitrep11Oct20eng.pdf.

Widodo, Mulyo Manggih \& Lisnawati Ruhaena. (2018). "Lingkungan Literasi di Rumah pada Anak Pra Sekolah” Indigenous: Jurnal Ilmiah Psikologi, 3(1). https://doi.org/10.23917/indigenous.v3i1.3059.

Yensy, Nurul Astuty. (2020). "Efektivitas Pembelajaran Statistika Matematika Melalui Media WhatsApp Group Ditinjau dari Hasil Belajar Mahasiswa (Masa Pandemik Covid 19)" Raflesia:Jurnal Pendidikan Matematika, 5(2). https://doi.org/10.33449/jpmr.v5i2.11410.

Yin, Robert K. (2009). Case Study Research: Design and Methods. California: SAGE Inc. 